\title{
The application of traditional culture in modern environmental art design
}

\author{
Chen Zhuohao ${ }^{1, \text { a }}$ \\ ${ }^{1}$ Jiangxi college of foreign studies,NanChang,330099, China \\ a ChenZhuohao@yeah.net
}

Keywords: Traditional culture; Modern environment; Environmental art; Art design; Application embodiment.

\begin{abstract}
A country of different age art design style, always draw nourishment from the tradition, resonate with the needs of the times, which form new test stand the history of design, will also become the future of the tradition, and in this cycle in the development of. Our country since joining the WTO, the trend of economic globalization and cultural internationalization is more and more obvious, the cultural influence between different ethnic groups is increasing, the development of science and technology, the concept of conflict between old and new culture, change development of environmental art design style, works of art and design without national characteristics is difficult to gain a foothold in the world. How to promote the development of environmental art design style with the combination of modern culture and traditional culture has become the focus of attention of contemporary designers. Art is a kind of creative activity of human being and its result, it is a kind of active aesthetic response to life. Art works are the physical and chemical forms of the people based on the objective reality. Is an important part of human civilization? China, with a long history of 5000 years, deep in the history of art intension, change and progress of human civilization at the same time, works of art, the era of celebrity men, make money is an example for contemporary human civilization. The creator of traditional art is the mass of the Chinese nation. Design in the field of contemporary design is a practical art, must have a purpose. The object of design is the product, the essential purpose of the design is the person. People will design and design, in which the traditional elements of the essence of the traditional elements of the combination of the rhyme, so as to achieve the purpose of the design.
\end{abstract}

\section{Introduction}

With the development of society and the improvement of quality of life, people on the interior space of the material and spiritual function and a new understanding of modern interior decoration design and material function is no longer the only elements of design, the function of the spirit of nationalism, personalized and diversified increasingly attracted enough attention, how to apply the traditional the aesthetic elements are fully reflected in the modern interior decoration design, which has become a new problem of designers and researchers constantly thinking and exploration. It should be recognized that many designers of Chinese traditional elements of understanding and use are relatively in place, many of their works are refreshing, get the domestic and foreign colleagues and the appreciation of the person's praise. However, through the noisy bustling surface phenomenon, we will find that a lot of praise ideas actually only stay on the surface. Chinese traditional culture is an important part of the essence of Chinese traditional culture, its production and spread is enough to prove its tenacious vitality and social life is closely related to the blood relationship. Therefore, it is no doubt that the introduction of modern interior design is the inheritance of traditional culture. Now Chinese, people increasingly rapid pace of life[1], frequent exchanges with foreign China leads to many aspects of design style of the western countries in China in the field of design has impact on the environmental art design has also become a popular trend, but China elements as a kind of our traditional culture should be inherited and developed. Let not lose the essence of rhyme culture era. In much domestic and foreign environmental art design, the use of Chinese elements occupies an important position. China traditional elements of the reason why there is such a high social status, this is cannot do without the traditional culture of the creators of life cognition, and the stubborn ability to 
create, let the traditional things undergo historical textual research, has left into the field of contemporary environmental art design. To know the elements of traditional culture must first know the traditional culture, the so-called "traditional culture" refers to the common, Confucianism as a baseline, subsumes other different ideological and cultural content of the organic composition of the system of Chinese nation. Chinese traditional culture is the inheritance of Chinese culture, it emphasizes the origin of Chinese culture and heritage of the objective existence of cultural heritage. And from the traditional culture, we can call it the traditional culture. Chinese traditional culture is a unique landscape and precious wealth of the eastern culture, it has its unique characteristics: first, it has diversity, it has a wide range of subjects, rich content and diverse forms. The elements of traditional culture also covers a very wide, the following list of small elements: Chinese calligraphy, seal carving, China knot, Qin Zhuanhan tile, Peking Opera mask, shadow, Chinese Han Dynasty lacquer, bamboo, Oracle, the "scholar's four jewels" (Yantai, brush, paper, ink) vertical cable filled with books, paper-cut, kite, Ruyi pattern, auspicious clouds pattern, Chinese embroidery (embroidery), water hyacinth, pottery, porcelain teapot, China, painting, Dunhuang murals, Shishi, costume, chopsticks, gold, Ruyi, Chinese characters, gossip etc.. Second, it has a historic, the Chinese civilization up and down five thousand years, and the formation of a long history of cultural knowledge, spread far. In the forest of world art, its unique charm. Chinese traditional culture is based on the understanding of the expression of traditional culture and art, to transform and use, to make it more of the characteristics of the times[2].

\section{The relationship between elements of Chinese traditional culture and modern environmental design}

An overview of the application of traditional culture. The use of ancient traditional cultural elements in modern environmental art design. Open the ancient architectural materials, the dignity of the Royal Palace, quiet temple, the elegant name of the house patterns abound. Remains of the Imperial Palace, the Summer Palace, the Old Summer Palace ruins, Qiao family courtyard and many Jiangnan, can be said to be a showcase of traditional cultural elements China. With the development of the times, the traditional culture elements have been gradually forgotten by people. In the traditional sense of the elements in the modern environment art design is more just a starting point. Today, the modern environmental art design has been given a new meaning. It refers to the design of the overall effect of the building surface and internal fixed surface decoration can be moved by the visual layout, the emphasis on the art of indoor floor, wall and ceiling of the interface, taking into account the door, window, furniture, curtains, carpets, lighting, furnishings and other craft. Is in line with the modern people's pursuit of the form of national, personalized, diversified aesthetic needs of modern environmental art design. In contemporary China, people are not only concerned about the interior design, not only in the rest and sleep, but also concerned about people's safety, health, efficiency, comfort and so on. Therefore, the pursuit of personalized living space has become an important concept of modern life. More and more attention has been paid to the design of modern environmental art. At the same time, the spiritual function is put in a very important position. In this case, the use of modern environmental art designers and researchers. The designer according to their own preferences, or European style design, Japanese, Korean, or Chinese and Western style design. But no matter what kind of type, after all to grow in this soil China, therefore, Chinese type naturally become an old topic, as long as it is China type, it must be the traditional type, but as long as the traditional style, also certainly cannot do without China elements of traditional culture. In general, people are still in an exploration stage for the use of Chinese traditional cultural elements in modern environmental art design. That is to recognize the elements of traditional culture is the embodiment of the essence of the culture of the elements, are willing to use; but how to use, the idea is not clear. To the traditional pattern of reference is a mere formality[3], is often mechanically superficial and one-sided.

The application of Chinese traditional culture in environment design. Western designs that ": there is no Chinese element, often there is no expensive gas." Nowadays one of the most fashionable 
household styles, it is given priority to with western style of decoration and furniture, mixed into one or two pieces of Chinese style furniture, and often produces stunning results. In fact, after thousands of years, it is visible to the Chinese style furniture, after the ebb tide is classical, so also has the extremely high fusion. We focused on Chinese style furniture, besides considering the material of it, I'm afraid should pay more attention to its internal design reflects a kind of household wisdom of the Chinese people. The application of traditional culture and modern civilization to the design style of Chinese elements, emphasizes the function and form of perfect and unified. The fusion of Chinese traditional elements and modern interior design is embodied in the reasonable solving function used in the creative first, make a design performance and function. Traditional culture elements and the integration of contemporary and contracted design interior design is not pure element symbols of but through understanding of traditional culture, the concept of contemporary and contracted design and traditional elements together. In modern people's aesthetic demand to make rich traditional styles of things, make the traditional culture elements and art in today's society find suitable reflect. Therefore, we can use the Chinese traditional elements and cultural symbols as background with the modern minimalist style of traditional Chinese elements and symbol extraction and secondary design, the rich connotation of Chinese culture and elements more concise, more symbolic shown in modern minimalist style.

Application analysis of Chinese traditional culture. The symbol of Chinese traditional culture and the design idea in the application of interior design is nowadays one of the most fashionable household styles with western style and decorative furniture is given priority to, mixed into one or two pieces of Chinese style furniture, often produce stunning results. After thousands of years, it is visible to the Chinese style furniture, has the extremely high fusion. But if material, lines, color collocation is not, it is easy to receive the opposite effect. In order to more in line with the requirements of living, choosing the right Chinese elements[4], can let a bedroom quaint and the force of pure and fresh. (1) the table. The table in the Chinese style furniture has a long table, square table, desk, kang table, etc. Hall square table is a facade, usually have to take the good hardwood, modeling sedate solemn, do manual work is delicate, exquisite decorations. (2) the case. And subdivided into GongAn, projects, book. GongAn usually display in the hall, used more as a decorative carving. Case in the sacred occasion, then the picture, the case is the life, which kind of furniture is to be able to reflect the aesthetic characteristics of Chinese literati. (3) the chair. The chair of Chinese style furniture, palace chair, the official cap chair, round-backed armchair, different chairs have different size, the qing palace chair largest, often is in the hall. (4) the bed. At present, we can see the Chinese style bed, four-post type or six pillar type frame, shelves can be surrounded on the veil, bed top lid. Chinese style and aghast bed, bed is a bit like widen the bar chair, no shelf, usually in the den with during my lunch break. Each piece of Chinese style furniture is like a classic old songs, in each flow of notes contain deep lasting appeal, only to savor, to realize some philosophy to its unique charm will attract a lot of attention. Of course, if the material of Chinese style furniture, lines, and color collocation is not in place, it is easy to receive the opposite effect, in order to more in line with the requirements of living, to choose the proper Chinese elements to make appeal quaint and clean the bedroom. Chinese style furniture has a long history, it is an important part of cultural heritage in our country, also is the shinning pearl of the treasure house of world furniture. Chinese traditional furniture, especially as a symbol of the Oriental furniture, Ming and qing furniture with its dignified, calm modeling and ring of craft, show to the world of primitive simplicity, elegant style, carrying the profound Chinese traditional culture inside information. Form is the most pure, the most obvious characteristics of the Ming and qing furniture two big series. The bright type furniture material selection standards, much depends on the material model, the pursuit of the natural grain of lumber. So our country tradition furniture multi-purpose a large number of high-quality timber, including red sandalwood, chrysanthemum pear, nanmu, chicken wing wood, etc. In order to be able to reflect a set of excellent traditional furniture, the interior design of the whole tonal go up, will be more effort to study and scrutiny. In the use of traditional furniture and modern interior design, color collocation of the traditional Chinese style furniture itself is there are many exquisite, don't make this the mass-tone attune of the interior design for all wood is tonal, make the room is too red. Such room 
design is also too dull, not suitable for family members living, use for a long time. As a designer, should be based in the traditional furniture, reform, and development function. Foster strengths and circumvent weaknesses, to develop Chinese traditional furniture. In many modern household design elements, Chinese style occupying very important position. With the development of The Times, the international design world began to pay more and more attention to the use of Chinese style element and symbol, now in our country the Chinese element is widely used in interior design work is that it is extremely widely used in the design basis. Refer to the new manufacturing technology, the form to include China's elements of style, is the solution of match well of Chinese and western. No matter now or in the future, China will become one of the important elements of interior design. As a designer, how to make innovation, blend in perfect traditional Chinese elements into the interior design of a required subject to try. Will import some modern elements, combination of pragmatism and functional, form characteristic of modern Chinese style design. As a modern interior decoration designers, it is necessary to integrate the Chinese elements in interior design, with the globalization tide and the popularity of new classicism, east China's traditional culture elements will be excavated, and continue to our modern life, more have the effect of a national culture inheritance, as people understanding of modern interior space, Chinese traditional culture elements will be more and more clearly benefit from the life of people.

\section{Modern environmental art design}

Summary of environmental art design. Environmental art design, is an emerging, edge, comprehensive art system engineering, is an interdisciplinary comprehensive professional, involving art, sculpture, landscape, garden, design history, psychology, material science, architecture, building decoration, ergonomics, and other fields, no matter in the breadth of the professional theory, or on the diversification of professional skills, have certain representativeness. Famous environmental art theorist "explained:" the environment design as an art, it is bigger than building, broader than planning, more emotional than engineering. It is a meddlesome art, encompassing art, early attention by traditional art ". With the rapid development of modernization and urbanization, environmental art design is becoming more and more cause the attention of people from all walks of life and value, environmental art design is to meet the demand of human physiological and psychological needs, build suitable for human survival, is beneficial to human activity, he combined traditional elements of rhyme, create the whole space art atmosphere and artistic conception [5].

China's western design pattern in the field of environmental art design. As exchanges around the world, in many areas in our country at present is to many the influence of foreign culture, it is both good and bad thing for our Chinese, give a person a kind of both joy and fear. China is an ancient civilization, has numerous human civilization. However, such an ancient civilization in the modern environmental art design is seldom belongs to its own local civilization concept and pattern evolved out of the building environment, blind worship system in the west, making China the design of the lost. In the lost in the design of traditional flavor.

The design of the traditional lack of continuity. In our country, many in the true sense to save the Chinese traditional architectural environment design thinking and practice cases, mostly concentrated in the remote countryside, they also more remain the local regional culture characteristics. For example, the ancient city of lijiang in yunnan province, sichuan LangZhong town, anhui hong cun, XiDi etc. Ancient residential buildings, as well as the external environment, there can be said to be the representative of Chinese traditional architectural environment design thinking and practice. And as the invasion of the western design concept, spatial structures of the Chinese vernacular architecture that self-sufficiency, also gradually be eroded. Inheritance, innovation and keeps improving through reforms the traditional cultural elements of effective use, to make a strong contemporary design and unique flavor. Under the condition of today's society, innovation is the premise of our design, the first is modern, is China's at the same time. If it is in a certain area, but also reflect the local characteristics, that is rooted in age and the real good works full of acrostic breath. 
Used in the design of the visual form of traditional culture, such as color, grain, shape and so on, then into the lifestyle of modern people. This design will be more capable the continuation of history.

\section{Summary}

Whether China or foreign design in the ultimate nature of the interpretation of the people-oriented, with a strong subjective color. Today's China is densely populated, living standards are rising, the country is also constantly moving forward, so the design of people-oriented to keep up with the pace of the times, in the traditional inheritance and development. The development of environmental art design in our country should take a suitable not only for our own national conditions, but also to follow the trend of the times of the Chinese cultural characteristics of the road, for the creation of traditional culture and show China works. The application of traditional culture in the modern environmental art design is a new perspective. Traditional elements should be combined with the modern environmental design, should be the spirit of the traditional elements in the design of the natural reflection, not simply put the traditional elements in any design. The process of design is a process of emotional cognition, and the application of traditional culture elements in the design of the national culture is revealed.

\section{References}

[1] Chen Xiaoying. Research on the modern environmental art design of personalized [J]. modern decoration (Theory). 2016 (05).

[2] Zhang Zhigang. The traditional culture in modern environmental art design [J]. art education. 2015 (05).

[3] Li Xibin. The traditional culture in modern environmental art design [J]. modern decoration (Theory). 2014 (02).

[4] Zhu Sasa. Modern environmental art design expression research [J]. modern decoration (Theory). 2014 (03).

[5] Wang Gang. The study of lacquer art in modern environmental art design combined with modern decoration [J]. (Theory). 2014 (06). 